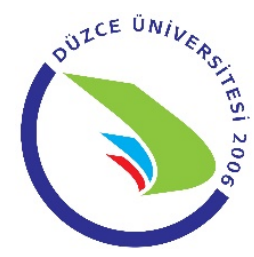

ORIJINAL MAKALE / ORIGINAL ARTICLE

Düzce Üniversitesi Sağlık Bilimleri Enstitüsü Dergisi / DÜ Sağlık Bil Enst Derg

Journal of Duzce University Health Sciences Institute / J DU Health Sci Inst

ISSN: 2146-443X sbedergi@duzce.edu.tr 2019; 9(3): 110-114

doi: https://dx.doi.org/10.33631/duzcesbed.538681

\title{
Yara Örneklerinden İzole Edilen Mikroorganizmaların Antimikrobiyal Direnç Oranları - Üç Yıllık Değerlendirme
}

\author{
Fatma AVCIOĞLU 國 ${ }^{1}$, Mustafa BEHÇET 國, Şeyda KARABÖRK 國, \\ Muhammet Güzel KURTOĞLU ${ }^{1}$
}

ÖZ

Amaç: Yara yeri enfeksiyonları, hastane kaynaklı enfeksiyonlar arasında ilk üç sırada yer almaktadır. Yara enfeksiyonlarının tedavisi sırasında kültür ve antibiyogram duyarlılıklarının yapılması, tedavinin başarısını arttıracağı gibi uygunsuz antibiyotik kullanımını engelleyerek, etken olan bakterilerde direnç gelişimini de önleyecektir. Çalışmamızda, 2016-2018 yılları arasında polikliniklere ayaktan başvuran ya da servislerde yatarak tedavi gören hastaların yara yeri örneklerinden izole ettiğimiz mikroorganizmaların dağı̆ımı ve antibiyotik duyarlılıkları belirlenerek, ampirik tedavi seçeneklerine yol gösterici olması amaçlandı.

Gereç ve Yöntemler: Hastanemiz mikrobiyoloji laboratuvarına gönderilmiş olan, toplam 315 yara yeri örneği retrospektif olarak incelendi. Etken olarak kabul edilen mikroorganizmaların tür düzeyinde tanımlanmaları ve antimikrobiyal duyarlılıkları araştırıldı.

Bulgular: İzole edilen mikroorganizmaların \%46.4'ünü (n=146) Gram pozitif koklar, \%53'ünü (n=167) Gram negatif bakteriler ve \%0.6'sın $(\mathrm{n}=2)$ mantarlar (Candida albicans) oluşturdu. S. aureus \%21 oranında en sık, Koagülaz Negatif Stafilokok \%16 oranında ikinci sıklıkta, E. coli \%15 oranında üçüncü sıklıkta görülen bakteri oldu $(\mathrm{p}<0.001)$. Gram pozitif bakterilerde, direnç durumuna bakıldığında, S. aureus suşlarının \%16.7'sinin metisiline dirençli olduğu görüldü. Enterokoklar dahil Gram pozitif bakterilerde glikopeptid direncine rastlanmadi. E. coli ve K. pneumoniae suşlarında GSBL oranı (\%43.8; \%48.5) diğer Gram negatif bakterilere oranla daha yüksek bulundu $(\mathrm{p}=0.493)$. En yüksek antibiyotik direnç oranı \%70.8 ile ampisiline, en az direnç oranı $\% 2$ ile imipeneme karşı görüldü.

Sonuç: Yara enfeksiyonlarının sık etkenlerinden olan S. aureus ve E. coli’nin çalışmamızda, başta gastrointestinal karsinomu olan hastalarda olmak üzere oldukça yüksek oranda saptanması nedeniyle ampirik tedavide bu etkenlerin antibiyotik duyarlılıklarının göz önünde bulundurulması gerektiği düşünülmüştür.

Anahtar Kelimeler: Yara; antibiyotik; direnç.

\section{Antimicrobial Resistance Rates of Microorganisms Isolated from Wound Specimens - Three Year Evaluation}

\begin{abstract}
Aim: Wound location infections are among the first three of hospital-acquired infections. During the treatment of wound infections, culture and antibiogram sensitivities will increase the success of the treatment and prevent the use of the wrong antibiotics and prevent the development of resistance in the bacteria. In our study, between the years 20162018 outpatient and inpatient wound distribution of microorganisms isolated from samples from patients we determined the rate and antibiotic susceptibilities were meant to be guiding the empirical treatment options.

Material and Methods: A total of 315 wound sites were examined retrospectively in our microbiology laboratory. Descriptive microorganisms were determined at species level and antimicrobial susceptibility tests were investigated.

Results: Of the isolated microorganisms, 46.4\% ( $n=146)$ were Gram positive cocci, 53\% ( $n=167)$ were Gram negative bacteria and $0.6 \%(\mathrm{n}=2)$ were fungi (Candida albicans). S. aureus was the second most frequent coagulase negative staphylococcus (16\%), E. coli was the third most common $(15 \%)(\mathrm{p}<0.001)$. In the case of Gram positive bacteria, $16.7 \%$ of $S$. aureus strains were resistant to methicillin. There was no glycopeptide resistance in Gram positive bacteria including enterococci. The ESBL ratio in E. coli and $K$. pneumoniae strains (43.8\%, 48.5\%) was higher than the other
\end{abstract}

1 Bolu Abant İzzet Baysal Üniversitesi, Tıp Fakültesi, Tıbbi Mikrobiyoloji A.D., Bolu, Türkiye 
Gram negative bacteria ( $\mathrm{p}=0.493)$. The highest antibiotic resistance rate was found to be against ampicillin with $70.8 \%$ and to imipenem with a minimum resistance rate of $2 \%$.

Conclusion: In our study, S. aureus and E. coli, which are frequent agents of wound infections, were considered to be quite high in patients with gastrointestinal carcinoma. Therefore, it was thought that the antibiotic susceptibility of these agents should be considered in empirical treatment.

Keywords: Wound; antibiotic; resistance.

\section{GÍRIŞ}

Deri, insan vücudunda yer alan dış etkenlere karşı vücudumuzda bariyer olarak görev yapan en önemli doğal bağışıklık elemanlarından biridir (1). Çeşitli faktörler ile cilt bütünlügüüün bozulması ya da konağın immün sisteminin zayıfladığı durumlarda, deri ve deri altı dokularının patojen mikroorganizmalar tarafından tutulması ile yara enfeksiyonları oluşur (2). Yara yeri enfeksiyonları, hastane kaynaklı enfeksiyonlar arasında ilk üç sırada yer almaktadır (3). Özellikle cerrahi operasyonlardan sonra gelişen yara yeri enfeksiyonlarında, yanlış tanı ve tedavi gerek maliyet gerekse hasta sağaltımı açısından istenmeyen durumlar oluşturmaktadır (4). Yara yeri enfeksiyon etkenleri, enfeksiyonun geliştiği bölgeye ve risk faktörlerine göre farklılıklar gösterirler (5). Enfeksiyon etkenleri arasında, cilt florasinda bulunan mikroorganizmalardan Gram pozitif bakteriler en fazla yer almaktadır (6). Yara enfeksiyonlarının tedavisi sırasında kültür ve antibiyogram duyarlılıklarının yapılması, tedavinin başarısını arttıracağı gibi uygunsuz antibiyotik kullanımını engelleyerek etken olan bakterilerde direnç gelişimini de önleyecektir (7).

$\mathrm{Bu}$ çalışmada, hastanemiz mikrobiyoloji laboratuvarına gönderilen yara örneklerinden izole edilen enfeksiyon etkenlerinin, gönderen kliniklere göre dağılımı ve antibiyotik duyarlılıkları belirlenerek ampirik tedavilere 1şık tutulması amaçland.

\section{GEREÇ VE YÖNTEMLER}

2018/278 no'lu etik kurul onayı ile gerçekleştirilen bu çalışmada, hastanemiz mikrobiyoloji laboratuvarına 2016-2018 yılları arasında poliklinik ve servis hastalarından gönderilen, toplam 315 yara yeri örneği, retrospektif olarak incelendi. Bütün örnekler aerobik koşullarda, \%5 koyun kanlı, Eosin Metilen Blue ve Çikolata agar (RTA, Tükiye) besiyerlerine ekilerek, 2448 saat süreyle $37^{\circ} \mathrm{C}$ ' de etüvde inkübe edildi. Eş zamanlı olarak yara örneklerinden Gram boyalı preparatlar hazırlandı. Işık mikroskobunda x100 objektif ile lökosit, epitel sayısı ve mikroorganizmaların morfolojileri değerlendirildi. Ekim yapılan plaklar 48. saat sonunda Gram boyama sonuçları ile beraber incelendi. Mikroskopik incelemede, lökosit görülmesine rağmen epitel az/hiç görülmemesi durumunda örnekler kaliteli numune olarak değerlendirildi. Üreme saptanan plaklardaki mikroorganizmaların etken mi kontaminant mı ayrımı direk mikroskobik inceleme sonucuna göre karar verildi. Kontaminant bakteriler değerlendirmeye alınmadi. Gram boya sonucundaki verilerle kolonileri tanımlamak, antibakteriyel duyarlılıklarını tespit etmek için konvansiyonel yöntemler ve otomatize sistem VITEK 2 (bioMerieux/ France) kullanıld1. Antibakteriyel duyarlılık sonuçları, EUCAST(European Committee on Antimicrobial Susceptibility Testing) kriterlerine göre yorumlandı (8). Colistin duyarlılık testi için sıvı mikrodilüsyon yöntemi yapılmadı. Tam otomatize identifikasyon sistemi sonuçlarına göre değerlendirildi.

\section{İstatistiksel Analiz}

Veriler frekans ve yüzdelerle özetlendi. Veri dağılımları göz önünde bulundurularak gruplar arasındaki farklar tek örneklem için ki-kare uyum iyiliği testi, Pearson ki-kare testi ve Fisher'ın kesin testi kullanılarak karşılaştırıldı. İstatistiksel testler için anlamlılık düzeyi $\mathrm{p}<0.05$ olarak kabul edildi.

\section{BULGULAR}

Çalışmamızda mikroorganizmaların izole edildiği hastaların yaşları 18-91 yaş aralığında idi. Toplam 315 etkenin 31'ini yoğun bakım, 105'ini servis ve 179'unu poliklinik hastaları oluşturdu. İzole edilen mikroorganizmaların \%46.4'ünü $(n=146)$ Gram pozitif koklar, \%53'ünü $(n=167)$ Gram negatif bakteriler ve \%0.6'sını (n=2) mantarlar (Candida albicans ) oluşturdu $(\mathrm{p}<0.001$; Tablo 1). Staphylococcus aureus (S. aureus) $\% 21$ oranında en s1k, Koagülaz Negatif Stafilokok (KNS) \%16 oranında ikinci sıklıkta, Escherichia coli (E. coli) $\% 15$ oranında üçüncü sıklıkta görülen bakteri oldu $(\mathrm{p}<0.001)$.

Tablo 1. İncelenen toplam örnek sayısının mikroorganizmalara göre dağılımı [n(\%)]

\begin{tabular}{|c|c|c|c|c|}
\hline $\begin{array}{c}\text { Toplam } \\
\text { Örnek } \\
\text { Sayısı }\end{array}$ & $\begin{array}{c}\text { Gram } \\
\text { Pozitif } \\
\text { Bakteri } \\
\mathbf{n ( \% )}\end{array}$ & $\begin{array}{c}\text { Gram } \\
\text { Negatif } \\
\text { Bakteri } \\
\mathbf{n}(\%)\end{array}$ & $\begin{array}{c}\text { Maya } \\
\mathbf{n}(\%)\end{array}$ & $\mathbf{p}^{\mathbf{a}}$ \\
\hline 315 & $146(\% 46.4)$ & $\begin{array}{l}167 \\
(\% 53.0)\end{array}$ & $2(\% 0.6)$ & $<0.001$ \\
\hline
\end{tabular}

${ }^{\mathrm{a}}$ Pearson ki-kare testi.

Tablo 2'de bakterilerin kliniklere göre dağılımı ve p değerleri gösterildi. Toplam izole edilen $S$. aureus, KNS, E. coli suşlarının sırasıyla \%74.2, \%64.7, \%54.2'si ayaktan başvuran hastaların yara örneklerinde saptanmıştır $(\mathrm{p}<0.001)$. Klebsiella spp., Enterococcus spp., Acinetobacter baumannii suşlarının ise çoğunluğu (\%60.6, \%55, \%93.8) yatan hastaların (yoğunbakım ve servis) yara örneklerinde saptanmıştır $(p<0.002, p<0.026$, $\mathrm{p}<0.022)$.

Direnç oranları incelendiğinde Gram pozitif bakterilerde metisilin direnci, S. aureus'ta \%16.7, KNS'de \%58.8 oranlarında saptandı $(p<0.001)$. En yüksek ve en düşük direnç oranları sırasıyla S. aureus'ta penisiline \%51.5, fusidik asite \%1.5, KNS'de penisiline \%45.1, fusidikasit ve trimetoprim/sülfametaksazole karş1 \%31.4 olarak saptand1. Enterokoklar dahil Gram pozitif bakterilerde glikopeptid direncine rastlanmad. Gram pozitif bakteriler için direnç oranları ve p değerleri Tablo 3'te gösterildi. Gram negatif bakteriler, direnç durumları incelendiğinde E. coli için Genişlemiş spektrumlu beta laktamaz (GSBL) pozitifliği \%43.8 olup en yüksek antibiyotik direnç oranı $\% 70.8$ ile ampisiline, en az direnç oranı ise \%2 ile imipeneme karşı görüldü. 
Tablo 2. Yara kültürlerinden izole edilen mikroorganizmaların kliniklere göre dağılımı [n(\%)

\begin{tabular}{|c|c|c|c|c|c|}
\hline $\begin{array}{l}\text { Etken } \\
\text { Mikroorganizmalar }\end{array}$ & $\begin{array}{c}\text { Yoğun bakım } \\
\text { n (\%) }\end{array}$ & $\begin{array}{l}\text { Servis } \\
\text { n (\%) }\end{array}$ & $\begin{array}{c}\text { Poliklinik } \\
\text { n (\%) }\end{array}$ & $\begin{array}{c}\text { Toplam } \\
\text { n (\%) }\end{array}$ & $\mathbf{p}$ \\
\hline Staphylococcus aureus ${ }^{a}$ & $1(1.5)$ & $16(24.2)$ & $49(74.2)$ & $66(21.0)$ & $<0.001$ \\
\hline $\begin{array}{l}\text { Koagülaz Negatif } \\
\text { Stafilokok }^{a}\end{array}$ & $4(7.8)$ & $14(27.5)$ & $33(64.7)$ & $51(16.0)$ & $<0.001$ \\
\hline Escherichia coli $^{a}$ & $4(8.3)$ & $18(37.5)$ & $26(54.2)$ & $48(15.0)$ & $<0.001$ \\
\hline Klebsiella spp. $^{a}$ & $2(6.1)$ & $18(54.5)$ & $13(39.4)$ & $33(11.0)$ & 0.002 \\
\hline $\begin{array}{l}\text { Pseudomonas } \\
\text { aeruginosa }^{a}\end{array}$ & $6(20.0)$ & 7 (23.3) & $17(56.7)$ & $30(10.0)$ & 0.025 \\
\hline Enterococcus spp. $^{a}$ & $1(5.0)$ & $10(50.0)$ & $9(45.0)$ & $20(6.0)$ & 0.026 \\
\hline $\begin{array}{l}\text { Acinetobacter } \\
\text { baumannii }^{a}\end{array}$ & $10(62.5)$ & 5 (31.3) & $1(6.2)$ & $16(5.0)$ & 0.022 \\
\hline Enterobacter spp. $^{b}$ & 0 & $5(50.0)$ & $5(50.0)$ & $10(3.0)$ & 1.000 \\
\hline Proteus spp. & 0 & 0 & $9(100)$ & $9(3.0)$ & - \\
\hline Streptococcus spp. $^{b}$ & 0 & $3(33.3)$ & $6(66.6)$ & $9(3.0)$ & 0.508 \\
\hline Candida albicans & 0 & 0 & $2(100)$ & $2(-)$ & - \\
\hline Diğger $^{a}$ & $3(14.3)$ & $9(42.9)$ & $9(42.9)$ & $21(7.0)$ & 0.180 \\
\hline
\end{tabular}

${ }^{a}$ Tek örneklem için ki-kare uyum iyiliği testi. ${ }^{b}$ Fisher'ın kesin testi.

Tablo 3. Yara kültürlerinden izole edilen Gram pozitif bakterilerin antibiyotiklere direnç oranları [n(\%)]

\begin{tabular}{|l|c|c|c|c|c|}
\hline Antibiyotik & $\begin{array}{c}\text { S. aureus } \\
\mathbf{n = 6 6} \\
\mathbf{( \% )}\end{array}$ & $\begin{array}{c}\text { KNS } \\
\mathbf{n = 5 1} \\
\mathbf{( \% )}\end{array}$ & $\begin{array}{c}\text { Enterococcus } \\
\text { spp. } \\
\mathbf{n = 2 0} \\
\mathbf{( \% )}\end{array}$ & $\begin{array}{c}\text { Streptococcus } \\
\text { spp. } \\
\mathbf{n = 9} \\
\mathbf{( \% )}\end{array}$ & $\mathbf{p}$ \\
\hline Metisilin $^{\boldsymbol{a}}$ & $11(16.7)$ & $30(58.8)$ & - & - & $<0.001$ \\
\hline Klindamisin $^{\boldsymbol{a}}$ & $5(7.6)$ & $19(37.3)$ & 0 & $1(11.1)$ & $<0.001$ \\
\hline Gentamisin $^{\boldsymbol{a}}$ & $3(4.5)$ & $21(41.2)$ & - & - & $<0.001$ \\
\hline Siprofloksasin $^{\boldsymbol{a}}$ & $8(12.0)$ & $19(37.2)$ & $4(20.0)$ & 0 & 0.004 \\
\hline Eritromisin $^{\boldsymbol{a}}$ & $6(9.1)$ & $28(54.9)$ & 0 & - & $<0.001$ \\
\hline SXT $^{\boldsymbol{b}}$ & $6(9.1)$ & $16(31.4)$ & - & $1(11.1)$ & 0.007 \\
\hline Fusidik asit $^{\boldsymbol{a}}$ & $1(1.5)$ & $16(31.4)$ & - & - & $<0.001$ \\
\hline Vankomisin $^{\boldsymbol{a}}$ & 0 & 0 & 0 & 0 & - \\
\hline Ampisilin/penisilin & & & \\
\hline
\end{tabular}

${ }^{a}$ Fisher'ın kesin testi, ${ }^{b}$ Pearson ki-kare testi, SXT: Trimetoprim/sülfametoksazol, KNS: Koagülaz negatif stafilokok

Tablo 4. Yara kültürlerinden izole edilen Gram negatif bakterilerin antibiyotiklere direnç oranları [n(\%)]

\begin{tabular}{|c|c|c|c|c|c|c|c|c|}
\hline Antibiyotik & $\begin{array}{c}\text { E. coli } \\
\mathrm{n}=48 \\
(\%)\end{array}$ & $\begin{array}{c}\text { K. } \\
\text { pneumoniae } \\
\mathbf{n}=33 \\
(\%)\end{array}$ & $\begin{array}{c}\text { Enterobacter } \\
\text { spp. } \\
\text { n=10 } \\
(\%)\end{array}$ & $\begin{array}{c}\text { Proteus } \\
\text { spp. } \mathrm{n}=9 \\
(\%)\end{array}$ & $\begin{array}{c}P . \\
\text { aeruginosa } \\
\mathbf{n}=30 \\
(\%) \\
\end{array}$ & $\begin{array}{c}\text { A. } \\
\text { baumannii } \\
n=16 \\
(\%) \\
\end{array}$ & $\begin{array}{c}\text { Diğer } \\
\text { n=9 } \\
(\%)\end{array}$ & $\mathbf{p}^{a}$ \\
\hline İmipenem & $1(2.0)$ & $1(3.0)$ & $1(10.0)$ & 1 (11.1) & $6(20.0)$ & $13(81.2)$ & 1 (11.1) & $<0.001$ \\
\hline Amikasin & $5(10.4)$ & $5(15.0)$ & 0 & $4(44.4)$ & $3(10.0)$ & $10(63.0)$ & $4(44.4)$ & $<0.001$ \\
\hline Gentamisin & $8(16.7)$ & $9(27.3)$ & 0 & $6(66.6)$ & 4 (13.3) & $14(88.0)$ & $5(55.6)$ & $<0.001$ \\
\hline Siprofloksasin & 19 (39.6) & $16(30.3)$ & $3(30.0)$ & $4(44.4)$ & $6(20.0)$ & $16(100)$ & - & $<0.001$ \\
\hline Ampisilin & $34(70.8)$ & $29(87.8)$ & $3(30.0)$ & - & - & - & $4(44.4)$ & 0.001 \\
\hline SXT & $20(41.7)$ & $14(42.4)$ & $1(10.0)$ & $5(55.6)$ & - & $13(81.2)$ & $1(11.1)$ & 0.002 \\
\hline $\begin{array}{l}\text { Piperasilin/tazo- } \\
\text { baktam }\end{array}$ & 16 (33.3) & 15 (30.3) & $4(40.0)$ & $2(22.2)$ & $9(30.0)$ & $16(100)$ & $6(66.6)$ & 0.001 \\
\hline Sefuroksim & $25(52.1)$ & 17 (51.5) & $4(40.0)$ & $3(33.3)$ & - & - & $3(33.3)$ & 0.706 \\
\hline Seftazidim & 22 (41.7) & $16(48.5)$ & $4(40.0)$ & $2(22.2)$ & - & $16(100)$ & $1(11.1)$ & $<0.001$ \\
\hline Seftriakson & $23(47.9)$ & $17(51.5)$ & $4(40.0)$ & $2(22.2)$ & $9(30.0)$ & $16(100)$ & 3 (33.3) & $<0.001$ \\
\hline Gsbl(+) & $21(43.8)$ & $16(48.5)$ & $3(30.0)$ & $2(22.2)$ & - & - & - & 0.493 \\
\hline Kolistin & - & 0 & - & $2(22.2)$ & 0 & 0 & - & 0.009 \\
\hline
\end{tabular}

${ }^{\mathrm{a}}$ Fisher'1n kesin testi 
Acinetobacter baumannii'de colistine karşı direnç gözlenmezken siprofloksasin, piperasilin /tazobaktam, seftazidim ve seftriakson'a karşı \%100 dirençli saptandı. Non-fermantatif bakteriler dişında Gram negatif bakterilerde $\% 4$ karbapenem direncine rastlandı. Gram negatif bakteriler için direnç oranları ve p değerleri Tablo 4'te gösterildi.

Tablo 5. Diabetes mellitus ve Gastrointestinal karsinom'lu hastalardan izole edilen mikroorganizmaların dağılımı [n(\%)]

\begin{tabular}{|l|c|c|}
\hline Etken mikroorganizma & $\begin{array}{c}\text { Diabetes mellitus } \\
(\mathbf{n = 3 4 )}\end{array}$ & $\begin{array}{c}\text { Gastrointestinal } \\
\text { karsinom (n=36) }\end{array}$ \\
\hline Staphylococcus aureus & $11(32.4)$ & 0 \\
\hline $\begin{array}{l}\text { Koagülaz Negatif } \\
\text { Stafilokok }\end{array}$ & $4(11.8)$ & $3(8.3)$ \\
\hline Enterococcus spp & $2(5.9)$ & $4(11.1)$ \\
\hline Escherichia coli & 0 & $14(38.9)$ \\
\hline Acinetobacter baumannii & $3(8.8)$ & $6(16.7)$ \\
\hline $\begin{array}{l}\text { Pseudomonas } \\
\text { aeruginosa }\end{array}$ & $5(14.7)$ & $2(5.6)$ \\
\hline Klebsiella spp. & $1(2.9)$ & $5(13.9)$ \\
\hline Enterobacter spp. & $4(11.8)$ & $1(2.8)$ \\
\hline Diğer & $4(11.8)$ & $1(2.8)$ \\
\hline
\end{tabular}

Ayrıca yara kültüründe bakteri üremesi olan hastaların 34'ü Diabetes mellitus ve 36'sı Gastrointestinel karsinom tanısı ile izlenen hastalard1. Diabetes mellitus ve Gastrointestinel karsinomlu hastalardan izole edilen mikroorganizmaların dağılımı Tablo 5'te gösterildi. Diabetes mellituslu hastalarda en s1k metisilin duyarlı $S$. aureus (MSSA) 11/34 (\%32.4), Gastrointestinel karsinomlu hastalarda ise E. coli 14/36 (\%38.9) etken mikroorganizma olarak bulundu.

\section{TARTISSMA}

Mikrobiyolojik açıdan yara örneklerinin incelenmesi diğer örnek türlerine göre daha zaman alıcı ve dikkat gerektirmektedir. Yara enfeksiyonu düşünülen hastalarda, örnekler doğru şekilde alınmaz ise deri florasında bulunan bakteriler, etken mikroorganizma olarak izole edilebilir (9). Bu da uygunsuz antibiyotik kullanımına ve tedavi süresinin uzamasına yol açabilir. Mikrobiyoloji laboratuvarı tarafından etkenin doğru tespit edilmesi ve antibakteriyel duyarlılıklarının belirlenmesi, klinisyenin tedavisinde önemli kolaylık sağlamaktadır (10).

Ülkemizde yapılan çalışmalara bakıldığında, İzmir'de Yurtsever ve ark. (11) yara örneklerinden izole edilen etken mikroorganizmaların \%78.2'sini Gram negatif, \%21.8'ini Gram pozitif bakteriler, Afyonkarahisar'da Aşık ve ark. (12) \%71'ini Gram negatif bakteriler, \%21.2'sini Gram pozitif bakteriler, Malatya'da Görmeli ve ark. (13) \%75'ini Gram negatif bakteriler, \%25'ini Gram pozitif bakteriler, Cirit ve ark. (7) \%61.9’unu Gram negatif bakteriler, \%38.1'inde Gram pozitif bakteriler, Doğan ve ark. (14) \%80.2'sini Gram negatif bakteriler, \%19.8'ini Gram pozitif bakteriler, Gündem ve Çıkman (10) ise \%32.4'ünü Gram negatif, \%67.6'sını Gram pozitif bakteriler olarak tespit etmişlerdir. Genel olarak değerlendirildiğinde Gündem ve Çıkman dışında yapılan çalışmalarda, Gram negatif bakteriler ağırlıklı etken olarak izole edilmiştir. Benzer şekilde bizim çalışmamızda da etken mikroorganizmalar içinde Gram negatif bakterilerin anlamlı olarak daha yüksek $(\% 53)$ olduğu görülmüştür $(\mathrm{p}<0.001)$.

Yara kültürlerinden üretilen mikroorganizmaların tür dağılımlarına bakıldığında, Doğan ve ark. (14) en fazla izole edilen bakteriyi \%28.5 ile E. coli, \%15.6 ile Enterobacter aerogenes, \%14.8 ile S. aureus, \%14 ile Pseudomonas aeruginosa, \%7.1 ile A. baumannii, \%5.8 ile Klebsiellea. pneumoniae, \%4.2 ile Enterobacter cloaceae, \%1.7 ile Staphylococcus epidermidis, Bayram ve ark. (15) \%23.6 ile A. baumannii, \%12 ile $P$. aeruginosa, \%11.2 ile S. aureus, \%10 ile E. coli olarak belirlemişlerdir. Cirit ve ark. (7), izole ettikleri bakterilerin \%20.9'unu KNS, \%19.5'ini E. coli, \%13.7'sini S. aureus, \%12.8'ini ile P. aeruginosa ve $A$. baumannii, \%11.4'ünü diğer enterik bakteriler olarak belirlemişlerdir. Yurtsever ve ark. (11) izolatlarının \%26.8'ini E. coli, \%18.3'ünü $P$. aeruginosa, \%18'ini $S$. aureus olarak, Zafar ve ark. (16) \%41.2'sini S. aureus ve \%18.3'ünü Pseudomonas spp. olarak tespit etmişlerdir. Çalışmalardan da fark edildiği üzere, S. aureus ve E. coli izole edilen bakteriler arasında ilk siralarda yer almaktadır. Bizim çalışmamızda da en sık izole edilen bakterilerde ilk üç sırayı, \%21 oranında S. aureus, \%16 oranında KNS, \%15 oranında E. coli oluşturdu $(\mathrm{p}<0.001$; Tablo 2).

Yara örneklerinden izole edilen mikroorganizmalara antibiyotik duyarlılık testlerinin yapılması, akılcı antibiyotik kullanımına, direnç oranlarının azalmasına ve tedavi maliyetinin düşürülmesine katkı sağlamaktadır (17). Gram pozitif bakterilerde, vankomisin direnci incelendiğinde, Gündem ve Çıkman (10), Doğan ve ark. (14), Aşık ve ark. (12), Cirit ve ark. (7) tarafından yapılan çalışmalarda, vankomisin direnci tespit edilmemiştir. Benzer şekilde çalışmamızda vankomisin direnci Gram pozitif bakterilerde saptanmad1.

Yara enfeksiyonlarından metisilin dirençli S. aureus suşlarının izolasyonu, hastane enfeksiyonları açısından önem arz etmektedir. Çalışmamızda S. aureus suşlarının \%16.7'sinde metisiline karşı direnç saptandı. Ayrıca penisilin direnci \%51.5, klindamisin direnci \%7.6, eritromisin direnci \%9.1, gentamisin direnci \%4.5, TMP/SXT direnci \%9.1, siprofloksasin direnci \%12, fusidik asit direnci ise \%1.5 olarak tespit edildi. Ülkemizde yapılan diğer çalışmalarda, Gündem ve ark. (10) S. aureus suşlarında metisilin direncini \%21.8 olarak bildirirken, Doğan ve ark. (14) \%18.3, Yurtsever ve ark. (11) \%29 olarak bildirmişlerdir. Yapılan çalışmalarda, metisilin direncinin farklı oranlarda bulunması, bu direnci saptamak için kullanılan yöntemlerin farklı olmasından kaynaklanabileceğini düşündürmektedir.

Gram negatif bakteriler için GSBL pozitiflik oranı yurt içi çalışmalarda, E. coli için \%11.3 - \%50 ve Klebsiella spp. için \%28.6 - \%37.5 aralığında bildirilmiştir $(9,17-$ 19). Çalışmamızda E. coli ve K. pneumoniae suşlarında GSBL oranı diğer Gram negatif bakterilere oranla daha yüksek bulunmuştur. İstatistiksel olarak bu farklılık anlamlı bulunmamıştır ( $p=0.493$; Tablo 4). E. coli için tespit edilen GSBL oranı (\%43.8) ve K. pneumoniae için tespit edilen GSBL oranı (\%48.5) önceki çalışmalara göre yüksek bulundu. İmipenem ve amikasin, çalışmamızda 
izole edilen Gram negatif mikroorganizmalara en etkili antibiyotikler olarak saptandı. Bu veriler, ülkemizde yapılan diğer çalışmalarda bildirilen antibiyotik duyarlılık sonuçlarına benzerdir $(8,10)$. Gram negatiflerde, GSBL oranlarının daha yüksek bulunması, çalışmamızın yakın zamanda yapılmış olması ve direnç oranlarının gittikçe artmasından kaynaklanmış olabileceğini düşündürmektedir.

Bayram ve ark. (15) yaptıkları çalışmada, Pseudomonas spp. suşlarındaki direnç oranları piperasilin/tazobaktam için \%31, imipenem için \%46, siprofloksasin için \%25, meropenem için \%19 bildirilmiştir. Bessa ve ark. (18), direnç oranlarını piperasilin/tazobaktam için \%52.2, siprofloksasin için \%45.6, meropenem için \%30.4, olarak bulmuşlardır. Bizim çalışmamızda ise direnç oranları piperasilin/tazobaktam için \%30, imipenem için \%20, siprofloksasin için \%20 olarak bulundu. Bu iki çalışmaya göre direnç oranlarımızın daha düşük olduğu görüldü.

\section{SONUÇ}

Yara enfeksiyonlarının klinisyen tarafindan erken ve etkin tedavisi için etken mikroorganizmaların türü ve antibiyotik duyarlılıklarının tespiti önemlidir. Yara enfeksiyonlarının sık etkenlerinden olan $S$. aureus ve $E$. coli'nin çalışmamızda, başta gastrointestinal karsinomu olan hastalarda olmak üzere oldukça yüksek oranda saptanması nedeniyle ampirik tedavide bu etkenlerin antibiyotik duyarlılıklarının göz önünde bulundurulması gerektiği düşünülmüştür.

\section{Teșekkür}

İstatistiksel olarak değerli katkılarından dolayı Dr. Öğr. Üyesi Oya Kalaycıoğlu'na teşekkür ederiz.

\section{KAYNAKLAR}

1. Edwards-Jones, Valerie. Essential microbiology for wound care. United Kingdom: Oxford University Press; 2016.

2. MS. Complicated skin and soft tissue infection. J Antimicrob Chemother. 2010; 65(Suppl 3): iii35-44.

3. Owens CD \& Stoessel K. Surgical site infections: Epidemiology, microbiology and prevention. Journal of Hospital Infection. 2008;70(Suppl 2): 3-10.

4. Altan G, Mumcuoğlu I, Hazirolan G, Dülger D, Aksu N. Yara örneklerinden izole edilen mikroorganizmalar ve antimikrobiyallere duyarlılıkları. Turk Hij Den Biyol Derg. 2017; 74(4): 279-86.

5. Sesli E, Kaya S, Taş T, Arıdoğan CB, Demirci M. Cerrahi alan enfeksiyonlarında mikroorganizma profili ve antibiyotik duyarlılık durumu. Ankem Dergisi. 2006; 20(2): 89-93.

6. Citil MU, Mete E, Oğuz EO, Abban GM, Şahin B \& Kaleli İ. Investigation of the effect of ibuprofen on wound healing in experimental Staphylococcus aureus soft tissue infections. Mikrobiyoloji bulteni. 2015; 49(2): 166-80.

7. Cirit OS, Müderris T, Mizraklı AZ, Vurupalmaz Y, Barış A. Yara Kültürlerinden İzole Edilen Aerop Bakteriler ve Antibiyotik Duyarlılıkları. Türk Mikrobiyol Cem Derg. 2015; 44(1): 149-57.

8. European Committee on Antimicrobial Susceptibility Testing. Breakpoint tables for interpretation of MICs and zone diameters. Version 6.0, valid from 2016-0101 [Internet]. Basel, Switzerland: EUCAST [Cited: 30 November 2017]. Available from: http://www.eucast.org/ast_of_ bacteria/previous_versions_of_documents.

9. Güriz H, Çiftçi E, Gökdemir R, Aysev D. Ankara Üniversitesi Tıp Fakültesi Cebeci Hastanesindeki yara kültürlerinin değerlendirilmesi. Ankara Üni Tıp Fak Mec. 2001; 54(3): 231-5.

10. Gündem NS, Çikman A. Yara Kültürlerinden İzole Edilen Mikroorganizmalar ve Antibiyotik Duyarlılıkları. ANKEM Derg. 2012; 26(4): 165-70.

11. Yurtsever SG, Kurultay N, Çeken N, Yurtsever Ş, Afşar I, Şener AG ve ark. Yara yeri örneklerinden izole edilen mikroorganizmalar ve antibiyotik duyarlılıklarının değerlendirilmesi. ANKEM Derg. 2009; 23(1): 34-8.

12. Aşık G, Özoğuz P, Tünay H, Bulut A, Kaçar S, Bal A. Yara kültürlerinden izole edilen etkenler ve antibiyotik direnç profilleri. Cerrahi Sanatlar Dergi. 2014; 7(1): 18-22.

13. Görmeli G, Duman Y, Karakaplan M, Korkmaz MF, Tekerekoğlu MS, Selçuk EB, et al. Orthopedic Surgical wound infection: microorganisms and resistance figures. J Turgut Ozal Med Cent. 2015; 22(1): 13-7.

14. Doğan SŞ, Paköz NIE, Aral M. Laboratuvarımıza gönderilen yara yeri örneklerinden izole edilen mikroorganizmalar ve antibiyotiklere direnç durumları. Türk Mikrobiyol Cem Derg. 2010; 40(4): 243-9.

15. Bayram Y, Parlak M, Aypak C Bayram I. Three-year review of bacteriological profile and antibiogram of burn wound isolates in Van, Turkey. Int J Med Sci. 2013; 10(1): 19-23.

16. Zafar A, Anwar N, Ejaz H. Bacteriology of infected wounds - a study conducted at children hospital Lahore. Biomedica. 2007; 23: 1-4.

17. Ağalar C, Göçmen JS, Kılıç D, Kaygusuz S, Karabıçak Ç. Üçüncü basamak bir referans hastanesinde izole edilen metisilin dirençli stafilokok suşlarında duyarlılık. J Clin Exp Invest. 2012; 3(1): 71-4.

18. Bessa LJ, Fazii P, Di Giulio M Cellini L. Bacterial isolates from infected wounds and their antibiotic susceptibility pattern: Some remarks about wound infection. Int Wound J. 2015; 12(1): 47-52. 